\title{
Party transformation, leadership change and closeness to parties: the case of Italy, 2013
}

\section{Diego Garzia}

To cite this article: Diego Garzia (2017) Party transformation, leadership change and closeness to parties: the case of Italy, 2013, Contemporary Italian Politics, 9:1, 30-43, DOI: 10.1080/23248823.2017.1288844

To link to this article: https://doi.org/10.1080/23248823.2017.1288844

\section{Published online: 07 Feb 2017.}

\section{Submit your article to this journal $₫$}

III Article views: 125

Q View related articles $\asymp$

View Crossmark data

Citing articles: 1 View citing articles 


\title{
Party transformation, leadership change and closeness to parties: the case of Italy, 2013
}

\author{
Diego Garzia
}

Department of Political Science, University of Lucerne, Lucerne, Switzerland

\begin{abstract}
Previous studies have portrayed the personalisation of politics as a consequence of changes in the electoral market and the resulting transformations at the party level. However, empirical research has not reached a consensus on the degree to which this process has had an impact on citizens' voting choices. An emerging body of comparative literature would seem to support the idea that partyleader evaluations have become an actual driver of partisanship at the individual level. However, existing evidence on the topic is placed in some doubt by the cross-sectional design used. To the extent that both the dependent variable (i.e. partisanship) and the main predictor (e.g. leader evaluations) are measured at the same point in time, the causal dynamics underlying the relationship between partisanship and leader evaluations remain unclear. Against this background, this article takes advantage of a unique panel dataset assembled for the Italian National Election Study (ITANES) in November and December 2013. The time-frame of the survey allows for an unprecedented causal assessment of the effect of leadership changes (the PD and the LN) as well as party-label changes (from the PdL to FI and the NCD) on patterns of closeness to parties at the individual level. The results shed new light on the changing relationship between voters and Italian political parties, ever more focussed upon their leaders and their characteristics.
\end{abstract}

\section{ARTICLE HISTORY}

Received 21 January 2016

Accepted 12 March 2016

\section{KEYWORDS}

Partisanship; personalisation of politics; primary elections

\section{Introduction}

Since its introduction in the mid-1950s, the notion of partisanship has been subject to a considerable amount of attention by electoral researchers (for a review, see: Bartle and Bellucci 2009). At the heart of this enduring interest lies the basic observation that voters have some kind of generalised predisposition to support a particular party over time (Miller 1991). In the social-psychological approach presented over fifty years ago in The American Voter, party identification is conceived as a long-term affective orientation to a political party, rooted in early socialisation and based on an individual's objective location in the social structure (Campbell et al. 1960). However, with the progressive erosion of traditional cleavage parties undermining the very bases of class, religion and territory as sources of political identity, an alternative reading of 
partisanship has found increasing favour among scholars in recent years. The so-called attitudinal approach has focused in particular on the 'instrumental' concerns that give rise to partisanship. Campbell et al. $(1960,135)$ had already written about the role of attitudes as 'potential agents of change in the individual's basic partisan orientation'. A number of subsequent studies of the American case explored in detail the dynamic relationship between party identification and short-term attitudes, demonstrating the absence of a clear causal path running from the former to the latter (Page and Jones 1979; Fiorina 1981).

Drawing a sharp distinction between these two approaches does not necessarily imply that one perspective is correct and not the other. Like all political attitudes, partisanship is responsive to the particular set of political alternatives (i.e. the parties) available in the political system at a given point in time (Richardson 1991; Gunther and Montero 2001; Gunther 2005; Lobo 2008). In the First Italian Republic (1948-1994) the stability of party identifications was especially accentuated by the close link between primary groups and the main parties of the time. In such a context, partisanship was regarded as 'a form of social embeddedness, a closure in distinctive and separate political sub-cultures and enclaves which Italian mass parties were able to bring about' (Bellucci 2007, 58). Although the social-psychological approach provided a suitable explanation of the ties between voters and the (main) parties in pre-1994 Italy, the same approach does not seem appropriate for an account of the nature of mass partisanship in the Second Republic. Notwithstanding the clear lack of solid socioideological bases among contemporary Italian parties, the latter are nonetheless entities to which a substantial proportion of the electorate still feels close (Bellucci and Segatti 2010). On these bases, it has been hypothesised that the process of party change has transformed the nature of partisanship from a mere reflection of previous social identities into something that is the reflection of individual attitudes to more visible partisan objects, such as the parties' leaders (Venturino 2000; Barisione 2006; Garzia 2012). According to this interpretation, feelings of closeness should be brought back to the party in the form of its leader (Barisione 2009).

A growing body of comparative literature would seem to support the idea that partyleader evaluations have become an ever more important driver of partisanship at the individual level. ${ }^{1}$ When it comes to the case of Italy, a previous longitudinal study by Garzia and Viotti (2011) found an increasing correlation between voters' feelings of closeness to parties and their evaluation of party leaders across the period 1990-2008. However, there is some doubt about the robustness of these findings given the crosssectional design used. Since the dependent variable (i.e. partisanship) and the main predictor (e.g. leader evaluations) are measured at the same point in time, the causal dynamics underlying the relationship between partisanship and leader evaluations remain unclear. Processes of cognitive rationalisation may be at work, and the growing impact of leaders on partisanship might be simply due to the increasing relevance of the former within voters' evaluative frameworks. As for the few studies that have addressed the issue of simultaneity with panel data (Garzia 2012, 2013b) there is a further problem to be mentioned, namely, that the studies in question lack the 'exogenous shock' required to test causal effects in (natural) experimental situations. Parties and leaders do not change often, and even less so at election time. The problematic empirical implication is that parties and leaders may well have been there before the beginning of 
the panel study. As a result, causal mechanisms linking leader evaluations to the development of partisan ties are most likely to have had their effects before the window of observation was opened by the panel study. On these bases, the ideal setting for testing the causal effect of political leaders on partisanship would seem to be that of party and/or leadership change.

Against this background, the present article takes advantage of a unique panel dataset assembled by the University of Siena in collaboration with the Italian National Election Study (ITANES) in November and December 2013. The time-frame of the survey allows for an unprecedented causal assessment of the effect exerted by leadership change (in the cases of the Partito Democratico (PD) and the Lega Nord $(\mathrm{LN})$ ) as well as party denomination change (from the Popolo della Libertà (PdL) to Forza Italia (FI) and the Nuovo Centro Destra)) on patterns of closeness to parties at the individual level. The analysis is preceded by a short description of the Italian context and the reasons why this can be conceived a crucial test case for the 'personalisation of partisanship' hypothesis.

\section{The personalisation of politics in the second Italian republic}

The personalisation of politics should be seen as a process in which 'the political weight of the individual actor in the political process increases over time, while the centrality of the political group (i.e. political party) declines' (Rahat and Sheafer 2007, 65). McAllister (2007) identifies three key factors at the core of the personalisation hypothesis, namely, (i) a number of institutional reforms that have strengthened the role of prime ministers within the executive (presidentialisation); (ii) the pervasive mediatisation of politics; (iii) the progressive erosion of long-standing partisan loyalties (dealignment). In this sense, the Italian case can be considered a prototype of personalisation among established parliamentary democracies (Campus 2010, 5-6). As a matter of fact, the conditions described by McAllister were present simultaneously during the 1990s transition, that is, there was: (i) a majoritarian electoral reform in 1993; (ii) a rapidly growing tendency on the part of parties to resort to television as a result of Silvio Berlusconi's entering the field; (iii) a breakdown of the post-war party system.

Although the origins of this process have been traced back to the early 1980s (Pasquino 1990), it is only with the transition to the Second Republic that Italy becomes in many respects the ideal-typical 'personalised polity' (Calise 2004). With the fall of Berlin Wall in 1989, the Cold War pattern that marked Italian politics since the beginning of the 1950s lost its historical raison d'être. The 1992 elections, at that time perceived as a 'landmark in Italian political history' (Pasquino and McCarthy 1993, 1), witnessed the greatest shift in voting patterns ever observed until then. In a political climate characterised by pervasive instability, investigating magistrates in Milan began to uncover a series of enormous bribery scandals. The operation Mani Pulite resulted in the arrest of many leading politicians and, in turn, in the dissolution of the great majority of established governing parties just before the election of 1994 (Gilbert 1995). The disappearance of the First Republic's party system was accompanied by rising levels of public dissatisfaction with politics, which culminated in the 1993 majoritarian referendum: ' $(\mathrm{t})$ he way it was presented to the people, a majoritarian electoral law would enable them to directly choose the winning party or a coalition [...] the result of 
the election would no longer be a loose and flexible parliamentary majority, but a government - and a head of the government - directly chosen by the people' (Calise 2005, 90). About 95 percent of the electorate voted in favour of the new mixed/ majoritarian electoral system. ${ }^{2}$

The collapse of the old partitocrazia along with the introduction of a majoritarian electoral law produced highly favourable conditions for new political actors successfully to join the fray. In turn, the decision of Silvio Berlusconi to 'take to the field' sparked a sudden acceleration in the process of personalisation of Italian politics (Campus and Pasquino 2006). In 1994 Berlusconi established his own personal party, FI, which he owns in exactly the same sense in which he owns the three national TV networks on which he was - and still is - able to conduct campaigns heavily focussed on himself and his supposedly extraordinary qualities. Besides being the private property of its founder, FI has always been highly dependent on Berlusconi in a political sense, since the main reason for its existence has been to get him elected as Prime Minister. Berlusconi would keep absolute control over both the organisational and the communicational aspects of the party, creating an indistinguishable identity between the party and the man (Poli 2001). This moved some scholars to describe FI as a movement conceived and developed as Silvio Berlusconi's 'personal party' (Calise 2000).

Far from being an isolated exception on the political landscape of the Second Italian Republic, FI (as well as its later reincarnation, the PdL) paved the way for the wholesale replacement of traditional cleavage parties by largely personalistic parties and parties with personal leaderships (Musella and Webb 2015; Calise 2016). Focusing on the other major parties currently represented in Parliament, their post-organisational outlooks emerge quite clearly. The most illuminating case relates obviously to Beppe Grillo's Movimento 5 Stelle (M5S), clearly characterised by its almost complete dependence on the charismatic appeal of its leader and its lack of connections with any specific social stratum or category (Diamanti 2014). In the case of the LN, the marked ethnoregionalist appeal of the party (Tronconi 2005) for long sat beside a weak structure at least as compared to the powerful role played by founding leader, Umberto Bossi, in shaping the goals, strategy and policies of the party (Ignazi 1997). The central role of the party leadership - hand in hand with the 'nationalisation' of the party's electoral strategy - has grown further in recent years under the highly personalised leadership of Matteo Salvini. When it comes to the heirs of the Communist Party, they have followed the process of transformation that all Western class-mass parties has undergone in recent decades, with a progressive de-attachment from the socio-ideological cleavages with which they were usually associated being the most visible consequence (Mair, Müller, and Plasser 2004). This is especially evident in the process that led the former communists to merge with others - following a number of organisational and ideological changes - in the brand-new PD in 2007. In the 2008 campaign, the political supply was marked by an unprecedented degree of personalisation due to the PD's decision to focus its electoral strategy on its leader and prime-ministerial candidate, Walter Veltroni (Barisione and Catellani 2008). Eventually, the personalisation of the party reached a climax under the new leadership of Italy's last Prime Minister, Matteo Renzi (Barisione, Catellani, and Garzia 2013; Vicentini 2015).

The relative importance of each of these leaders $v i s$ - $a$-vis their respective parties leads to the expectation that, if anything, the relationship between individual feelings of 
closeness to parties and attitudes towards their leaders will have grown stronger in line with the trend that has already been described by Garzia and Viotti (2011). In the reminder of this article, however, I will refrain from longitudinal reassessments and focus on causal dynamics. The analysis thus aims at measuring the extent to which contemporary Italian party leaders are capable of shaping voters' feelings of closeness to their respective parties.

\section{Data and case selection}

The last general election in Italy was held on 24 and 25 February 2013. The problematic nature of the outcome resulted in a correspondingly long process of government formation, one that took over two months. On 28 April, the President of the Republic, Giorgio Napolitano, appointed Enrico Letta as the head of a unity government involving representatives of both the PD and the PdL. This parliamentary majority, however, lasted only until mid-November 2013, when Silvio Berlusconi led the PdL's withdrawal from the government and the simultaneous reversion of the name of his party to the original Forza Italia. This event led in turn to the formation of a smaller party - the Nuovo Centro Destra (NCD) - which, under the leadership of Angelino Alfano, decided not to withdraw from government and thus split from the PdL/FI. Just a few weeks later, on 7-8 December, the process of political change took another turn with the 'primary' elections for the leaderships of both the PD and the LN. Matteo Renzi became the new leader of the PD, while Matteo Salvini became leader of the LN.

Figure 1 presents a typology of Italian parties during the period under analysis based on whether they went through a process of leadership change and/or party (re)formation. The statistical analysis that follows will take into account both those parties that changed their leaders through 'primary' elections (i.e. the PD and the LN), and those that originated from the split of the PdL (i.e. FI and the NCD).

The data presented in this analysis comes from a CAWI panel survey conducted by SWG in collaboration with the University of Siena and ITANES. Respondents were interviewed before the exit of the PdL from government (fieldwork: 13-15 November;

\section{PARTY}

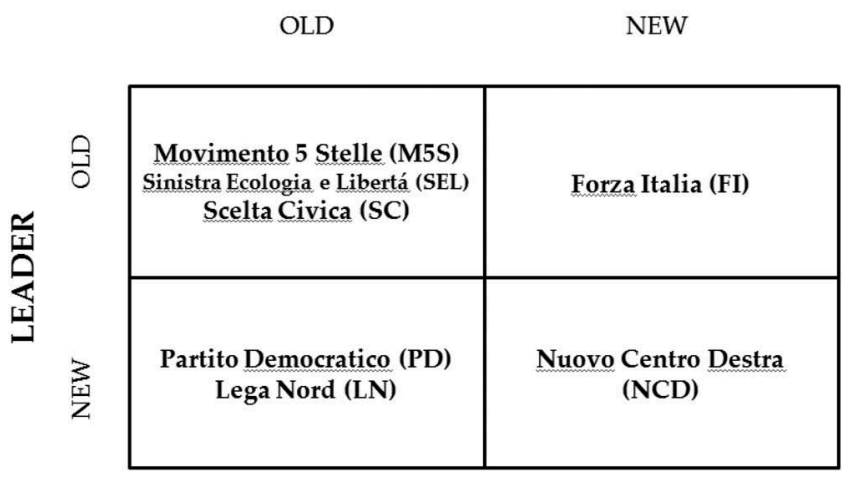

Figure 1. Party and leadership change in Italy: a typology. 
$\mathrm{N}=808$ ) and again a few days after the 'primary' elections held by the PD and the LN (fieldwork: 17-21 December; $\mathrm{N}=731$ ). The re-interview rate for the panel survey was a remarkably high $91 \%$. Only those respondents agreeing to be interviewed on both occasions are included in the analysis.

The dependent variable is the respondent's degree of 'closeness' to the major parties on a 10 -point scale. ${ }^{3}$ The key independent variables used to operationalise the attitudinal model are party-leader evaluations (i.e. thermometer scores on a 10-point scale) and ideological proximity to the parties (i.e. perceived distance between self and each party on a 10-point left-right scale). ${ }^{4}$ Mean values for all variables/waves are presented in Tables 13 below. A few patterns are worth noting. First, all instances of leadership change brought a significant improvement in voters' mean evaluations of the party leadership (Table 3 ). Regardless of these changes, however, voters' mean left-right proximity to the parties does not seem to be affected in any significant way (Table 2). Hence, the fact that the mean value of party closeness increases significantly for both parties that underwent a process of leadership change (Table 1) provides an initial indication that changing patterns of leader evaluation might have a role in driving changes in patterns of party closeness.

\section{Empirical analysis and results}

Moving to individual-level relationships, Table 4 presents the values of Pearson correlations between closeness to each of the parties (as measured in both waves) and a selected list of traditional socio-structural and attitudinal correlates of partisanship. Table entries highlight the comparatively much stronger relationship between partisanship and attitudinal

Table 1. Closeness to parties: across-wave stability (mean values).

\begin{tabular}{lllll}
\hline & November 2013 & & December 2013 & \multicolumn{1}{c}{$\Delta$} \\
\hline LN & 1.82 & LN & 1.85 & +0.03 \\
PD & 2.92 & PD & 3.18 & $+0.26^{*}$ \\
& & & & \\
PDL & 2.48 & NCD & 2.09 & $-0.39^{*}$ \\
& & FI & 2.54 & +0.06 \\
\hline
\end{tabular}

* t-test is significant at the .01 level (two-tailed)

Table 2. Leaders' thermometer: across-wave stability (mean values).

\begin{tabular}{llllc}
\hline \multicolumn{1}{c}{ November } & \multicolumn{2}{c}{ December } & \multicolumn{1}{c}{$\Delta$} \\
\hline LN (Maroni) & 2.72 & LN (Salvini) & 3.03 & $+0.31^{*}$ \\
PD (Bersani) & 2.77 & PD (Renzi) & 5.14 & $+2.37^{*}$ \\
& & & & \\
PDL (Berlusconi) & 2.69 & NCD (Alfano) & 3.25 & $+0.56^{*}$ \\
& & FI (Berlusconi) & 2.86 & $+\mathbf{0 . 1 7}$ \\
\hline
\end{tabular}

* t-test is significant at the .01 level (two-tailed).

Table 3. Party-voter proximity on the L/R scale: across-wave stability (mean values).

\begin{tabular}{lllll}
\hline \multicolumn{2}{c}{ November } & & December & $\Delta$ \\
\hline LN & 3.89 & LN & 3.86 & -0.03 \\
PD & 3.63 & PD & 3.51 & -0.12 \\
& & & & \\
PDL & 3.55 & NCD & 3.52 & -0.03 \\
& & FI & 3.63 & +0.08 \\
\hline
\end{tabular}

None of the t-tests performed here reaches the .01 significance level (two-tailed). 
Table 4. The correlates of partisanship.

\begin{tabular}{|c|c|c|c|c|c|c|c|}
\hline & \multicolumn{2}{|c|}{ Partito Democratico } & \multicolumn{2}{|c|}{ Lega Nord } & \multirow{2}{*}{$\frac{\mathrm{PdL}}{t 1}$} & \multirow{2}{*}{$\frac{\text { Forza Italia }}{t^{2}}$} & \multirow{2}{*}{$\frac{N C D}{t 2}$} \\
\hline & $t 1$ & $t 2$ & $t 1$ & $t 2$ & & & \\
\hline Gender & -.04 & -.03 & -.02 & -.07 & -.01 & -.05 & -.07 \\
\hline Age & $.10^{* *}$ & $.10 * *$ & .01 & .04 & -.00 & .03 & .05 \\
\hline Education & .07 & $.09^{* *}$ & -.01 & -.02 & .00 & -.03 & .05 \\
\hline Public-sector employee & .03 & .03 & -.02 & .02 & .05 & $.08^{*}$ & .01 \\
\hline Private-sector employee & .04 & .07 & -.01 & .03 & -.05 & -.07 & .06 \\
\hline Church attendance & .07 & .04 & .06 & .04 & $.12^{* *}$ & $.10^{* *}$ & $.19^{* *}$ \\
\hline Left/Right Proximity & $-.53^{* *}$ & $-.55^{* *}$ & $-.46^{* *}$ & $-.46^{* *}$ & $-.54^{* *}$ & $-.59 * *$ & $-.44^{* *}$ \\
\hline Leader Evaluation & $.69^{* *}$ & $.54^{* *}$ & $.70^{* *}$ & $.60^{* *}$ & $.79 * *$ & $.83^{* *}$ & $.58^{* *}$ \\
\hline
\end{tabular}

Table entries are Pearson's $r$ coefficients. ${ }^{* *} p<.01,{ }^{*} p<.05$ (two-tailed).

items (i.e. leader evaluations, ideological proximity) vis-à-vis voters' socio-demographic characteristics (i.e. age, gender, educational level) and their location in the socio-economic structure (i.e. occupational status, frequency of church attendance). However, the magnitude of the relationships cannot be equated with varying degrees of causal impact due to the potentially strong inter-correlation between predictors. Moreover, the possible endogeneity in the relationship between partisanship and attitudinal items (i.e. with favourable leader evaluations possibly being caused by pre-existing feelings of closeness to the party) cannot be accounted for in a cross-sectional setting.

Against this background, the reminder of the analysis will take advantage of the panel structure of the data in order to rule out the possibility of reverse causation, while simultaneity will be taken into account within a multivariate setting. First of all, I will concentrate on those instances in which 'the making of partisanship' can be captured in real time. Making use of Granger's notion of causality (i.e. what happens after cannot cause what happened before) I assess the determinants of partisanship for new parties. I do so through OLS estimation. The dependent variable is closeness (as measured at time t2) to FI and the NCD in turn. The regression analysis includes socio-demographic controls, socio-economic status (SES) predictors as well as our key attitudinal measures (a full list of covariates and variable codings is provided in Appendix 1). Clearly, these parties are not born in a vacuum, as they are both linked to an already existing party to which people had a certain degree of closeness. For this reason, the models also include a lag of the dependent variable (i.e. closeness to the PdL at time t1). ${ }^{5}$

What appears rather clearly from the results presented in Table 5 is that social structure does not seem to matter much - although the effect of the SES measures could possibly be absorbed by the lagged dependent variable. With regard to the lagged dependent variable itself, it clearly has a significant relationship with current partisanship. Surprisingly, however, it does not seem to matter as much as leadership evaluations (note that these variables are measured on the same 10-point scale, and hence the coefficients can be meaningfully compared in terms of their magnitude). The latter indeed appears to be the key variable in each of the models, with left-right proximity mattering only weakly, especially in the case of FI.

I now turn to the analysis of those parties that existed before the beginning of the panel and changed their leader across our two waves. Before looking into the drivers of change, it is useful to have a preliminary look at the direction of change, focusing on aggregate patterns of covariance, as presented in Table 6. Note that first differences are 
Table 5. The determinants of partisanship: OLS estimation.

\begin{tabular}{lcr}
\hline & $\mathrm{FI}$ & $\mathrm{NCD}$ \\
\hline Gender & $.07(.14)$ & $-.05(.17)$ \\
Age category & $-.06(.05)$ & $.06(.06)$ \\
Level of education & $-.04(.03)$ & $.07(.04)$ \\
Public-sector employee & $.30(.21)$ & $-.46(.26)$ \\
Private-sector employee & $.01(.17)$ & $-.06(.21)$ \\
Church attendance & $.02(.04)$ & $.10(.05)^{*}$ \\
Leader Evaluation (t2) & $.59(.03)^{* * *}$ & $.39(.03)^{* *}$ \\
Left/Right Proximity (t2) & $-.09(.03)^{* *}$ & $-.21(.03)^{* * *}$ \\
Closeness to PdL (t1) & $.31(.03)^{* * *}$ & $.27(.03)^{* * *}$ \\
Constant & $.86(.40)^{*}$ & $.75(.46)$ \\
R-Squared & .79 & .51 \\
$\mathrm{~N}$ & 553 & 553 \\
\hline
\end{tabular}

Dependent variable: Partisanship. Cell entries are OLS un-standardised regression coefficients (standard error in parentheses). ${ }^{* *} p<.001,{ }^{* *} p<.01,{ }^{*} p<.05$.

Table 6. Partisanship, leader evaluations and left/right proximity across panel waves.

\begin{tabular}{lccccr}
\hline Panel A: PD & Decrease & Stable & Increase & Total & Increase-Decrease \\
\hline$\Delta$ Partisanship & $23.3 \%$ & $44.7 \%$ & $32.0 \%$ & $100 \%$ & $+8.7 \%$ \\
$\Delta$ Leader Evaluation & $13.3 \%$ & $20.4 \%$ & $66.3 \%$ & $100 \%$ & $+53.0 \%$ \\
$\Delta$ Left/Right Proximity & $37.1 \%$ & $28.2 \%$ & $34.7 \%$ & $100 \%$ & $-2.4 \%$ \\
\hline Panel B: LN & Decrease & Stable & Increase & Total & Increase-Decrease \\
\hline$\Delta$ Partisanship & $19.4 \%$ & $60.1 \%$ & $20.5 \%$ & $100 \%$ & $+1.1 \%$ \\
$\Delta$ Leader Evaluation & $25.1 \%$ & $39.5 \%$ & $35.4 \%$ & $100 \%$ & $+10.3 \%$ \\
$\Delta$ Left/Right Proximity & $33.3 \%$ & $23.6 \%$ & $43.0 \%$ & $100 \%$ & $+9.7 \%$ \\
\hline
\end{tabular}

grouped into three major categories tapping whether values of a given variable have increased, decreased, or stayed exactly the same across waves.

There appears to be a rather high degree of instability in the data presented in the table, regardless of the party and/or the measure under analysis. The point of this analysis, however, is not to explain the magnitude of change, but rather to find out the extent to which change can be interpreted as the result of significant patterns of covariance across the variables of interest. Looking at Panel A, relative to the PD before and after the election of Matteo Renzi as party leader, one notes that the degree of closeness to the party remains stable for almost half of the sample. Yet, the value presented in the last column, indicating the percentage difference between respondents whose reported closeness to the party increased and those whose closeness decreased across the two waves, shows that the value of the partisanship variable has increased, overall, by as much as nine percent across the whole sample. When it comes to the main predictors of change, improving leader evaluations and decreasing distance on the ideological scale represent the modal categories (in bold). However, the improvement in leader evaluations is disproportionately higher. Two thirds of the sample reported an improvement in evaluations of the PD leader (Bersani vs. Renzi) across the waves, while only one third reported a decrease in distance on the ideological scale. In terms of individual-level relationships, it is worth noting that only leader evaluations co-vary in a significant manner with partisanship $(r=.19)$, while no significant relationship would seem to exist between partisanship and issue proximity differentials (and the same holds also for issue proximity and leader evaluations). Moving to Panel $\mathrm{B}$, relating to the $\mathrm{LN}$, the aggregate pattern reveals an improvement in leader evaluations and an increase in ideological proximity of equal size across panel waves. Yet 
the only significant relationship is that between differentials in partisanship and leadership evaluations $(r=.11)$.

To test these conclusions in a multivariate setting, I estimated two First Difference (FD) models. The FD estimator is intended to eliminate time-invariant omitted variables using repeated observations over time. In other words, estimation takes place by regressing 'changes on changes' using OLS (Wooldridge 2001). To put it more simply, changes in the extent to which a respondent feels close to a given party ${ }^{6}$ are explained as a function of across-wave changes $(\Delta)$ in the thermometer score of that party's leader and in the perceived distance between the respondent and the party on the left-right scale, controlling for basic socio-demographic and socio-structural variables, as measured at $t_{1}$. The results, presented in Table 7, point in the same direction as those of the previous analyses, and provide further support for the idea that across-time changes in patterns of party closeness are more strongly associated with voters' assessments of party leaders' personalities.

In order to test the robustness of these conclusions, I re-estimated the models presented in Tables 5 and 7 taking into account only those respondents reporting a great degree of closeness to the party (i.e. those rating their closeness to each of the parties under analysis with a score between 5 and 10). The results, presented in Appendix 2, show only minor differences from those presented above.

\section{Concluding remarks}

The results presented in this paper provide a number of suggestions concerning contemporary partisanship in the Italian case. Most of them are in line with theoretical expectations. By the end of 2013, closeness to Italian parties appears only marginally linked to voters' locations in the social structure. It seems rather driven by political forces and, in primis, by voters' assessments of the personality of the party leader. While previous work has highlighted problems when it comes to establishing the actual direction of the flow of causality, this paper has attempted to overcome such problems by resorting to a natural quasi-experiment. In order to shed new light on the drivers of change, I made use of a unique panel dataset assembled by ITANES during a short period of massive political change (i.e. November and December 2013). Placing exogenous change at the heart of the model, I found that liking the new leader better is a key variable for understanding changing (i.e. warmer) feelings towards the party across

Table 7. The drivers of change: first difference (FD) estimation.

\begin{tabular}{lcc}
\hline & LN & PD \\
\hline Gender & $-.15(.16)$ & $.29(.18)$ \\
Age category & $.01(.06)$ & $.04(.06)$ \\
Level of education & $-.06(.04)$ & $.02(.04)$ \\
Public-sector employee & $.61(.25)^{*}$ & $.16(.26)$ \\
Private-sector employee & $.39(.20)^{*}$ & $.09(.21)$ \\
Church attendance & $-.06(.05)$ & $-.13(.05)^{*}$ \\
SLeader Evaluation & $.09(.03)^{* *}$ & $.12(.03)^{* * *}$ \\
DLeft/Right Proximity & $-.03(.03)$ & $.05(.04)$ \\
Constant & $.25(.42)$ & $-.59(.45)$ \\
R-Squared & .04 & .05 \\
$\mathrm{~N}$ & 519 & 519 \\
\hline
\end{tabular}

Dependent variable: $\triangle$ Partisanship. Cell entries are OLS un-standardised regression coefficients (standard error in parentheses). ${ }^{* * *} \mathrm{p}<.001,{ }^{* *} \mathrm{p}<.01,{ }^{*} \mathrm{p}<.05$. 
time. Indeed, leadership evaluations would seem to matter a lot, not only as a source of attraction for parties who are 'unafraid of their supporters (i.e. the PD), but also as a sort of 'personalised counterweight' for parties who decide to move away from (in this case, in opposition to) centrist voters, as in the case of the re-born FI. Clearly, leaders cannot be the only answer, and probably not even the foremost one. It is plausible that leader evaluations are coloured by political and ideological factors as well (see Bellucci, Garzia, and Lewis-Beck 2015). Further research in this domain is called for, also in the light of the major implications of this 'personalisation' of partisanship.

When it comes to the unavoidable limitations of the present study, it must be highlighted that the analysis of the correlates and determinants of partisanship did not focus on the actual magnitude of these effects. However, a critical assessment of the empirical findings presented here should not downplay the rather small size of leader effects on partisanship. Focusing on the case of PD, Renzi's election resulted in a mean increase in the value of the leadership variable of about 2.4 points on a 10-point scale. Yet this resulted in increase on the partisanship variable of just 0.26 points. A comparable pattern is to be found in the case of the LN, with leadership increasing by 0.30 percentage points and partisanship increasing just by 0.03 percentage points. Table 6 provides an even more simplified interpretation of these figures. Take as an example the case of the PD once again. Across the two waves, almost one respondent in two (net aggregate value) reported that they liked Renzi more than Bersani. However, the increase in the proportion of voters feeling closer to Renzi's PD amounted to just 8 percent. A similar pattern (albeit of much reduced magnitude) can be witnessed in the case of the LN. Based on these findings, a rough estimate of impact would posit that it requires ten voters to like the leader more for just one of them actually to feel closer to the party... In turn, this would point to a somewhat paradoxical finding, namely, that an unusual improvement in party-leadership evaluation (as was the case, for instance, with Matteo Renzi in 2013) is necessary in order to generate a substantively small increase in closeness to the leader's party.

Another limitation of the analysis lies in its inability (due to the data at hand) to shed light on the long-term effects of leadership change. Indeed, the evidence presented so far does not make it possible to discard the hypothesis that increases in party closeness are merely epiphenomenal reactions to strongly mediatised events such as primary elections and the formation of new parties. If anything, this analysis of partisanship in a non-electoral period can be thought of as a suggestion that future research in the field focuses more closely on so-far neglected windows of observation, possibly in connection with longer panel studies able to take into account the behavioural implications of attitude change.

\section{Notes}

1. Comparative analyses of Western European democracies include various works by Garzia (2012, 2013a, 2013b). These analyses are replicated for Southern European democracies by Lisi (2014) and for Central and Eastern Europe by Flacco (2014). Marsh and Schwirz (2016) test this argument through CSES data, while Huang (2013) bases his analysis on Asianbarometer data.

2. The new electoral law (also known as the Mattarellum, after its principal parliamentary sponsor, Sergio Mattarella) entailed the election of 75 percent of Parliament's members through a first-past-the-post system, while the remaining 25 percent of the members were elected through a proportional system on a national basis.

3. Question wording was as follows: 'On a scale from 0 to 10, how close do you feel to each of the following parties?'. To be noted is that the question wording sacrifices 'the notion of long- 
term partisan identity for a feeling of closeness to a party [...] separate from vote choice' (Dalton 2010, 159).

4. Economic evaluations and performance assessments are not included in the model due to their considerable stability at the individual level across the short period of the panel study.

5. The inclusion of a lag of the dependent variable in the model also helps in controlling for the potential endogeneity in the relationship between closeness to the party and evaluations of its leader. By taking into account the amount of variance in the dependent variable due to pre-existing feelings of closeness to the (old) party, the analysis provides a more reliable estimate of the independent effect of leadership evaluations on individual-level patterns of closeness to the (new) party.

6. For example, if closeness to the PD in equals 5 at $t_{1}$ and 7 at $t_{2}$, then the value of the dependent variable for that respondent's closeness to the PD equals 2 .

\section{Acknowledgments}

Previous versions of this article were presented at the Political Science Departmental Seminar (Universitat Autonoma de Barcelona, March 2015), the Political Behaviour Research Group Seminar (Universitat Pompeu Fabra, Barcelona, March 2015), the Personalisation of Politics in the 21st Century: Final Conference (University of Lisbon, April 2015), the 9th ECPR General Conference (Universitè de Montreal, August 2015), and the 29th Annual Conference of the Italian Society of Political Science (Università della Calabria, September 2015). I wish to thank Guillem Rico, Romain Lachat, Marina Costa Lobo, Loes Aaldering, Daphne van der Pas, and Paolo Bellucci for organising these events and all the discussants and participants for their useful comments.

\section{Disclosure statement}

No potential conflict of interest was reported by the author.

\section{Notes on contributor}

Diego Garzia is Senior Research Fellow at the University of Lucerne. His current research project "Personalization of Politics between Television and the Internet", funded by an AMBIZIONE Grant of the Swiss National Science Foundation, investigates the extent to which political leaders have come to affect voters' choice as well as the role played by old and new media in driving this development across time. He sits in the Scientific Council of the Italian National Election Study (ITANES) and he is a co-convenor of the ECPR Research Network on Voting Advice Applications.

\section{References}

Barisione, M. 2006. L'Immagine del Leader. Quanto Conta per gli Elettori? Bologna: Il Mulino.

Barisione, M. 2009. "So, What Difference Do Leaders Make? Candidates' Images and the "Conditionality" of Leader Effects on Voting." Journal of Elections, Public Opinion and Parties 19 (4): 473-500. doi:10.1080/17457280903074219.

Barisione, M., P. Catellani, and D. Garzia. 2013. "Alla ricerca di un leader." In Voto Amaro, edited by ITANES. Bologna: Il Mulino.

Barisione, M., and P. Catellani. 2008. "L'offerta personalizzata degli sfidanti." In Il Ritorno di Berlusconi, edited by ITANES, 137-148. Bologna: Il Mulino

Bartle, J., and P. Bellucci, eds. 2009. Political Parties And Partisanship: Social Identity And Individual Attitudes. Abingdon: Routledge.

Bellucci, P. 2007. "Changing Models of Electoral Choice in Italy." Modern Italy 12: 55-72. 
Bellucci, P., D. Garzia, and M. Lewis-Beck. 2015. "Issues and Leaders as Vote Determinants: The Case of Italy.” Party Politics 21: 272-283. doi:10.1177/1354068812472583.

Bellucci, P., and P. Segatti, eds. 2010. Votare in Italia: 1968-2008. Bologna: Il Mulino.

Calise, M. 2000. Il Partito Personale. Roma-Bari: Laterza.

Calise, M. 2004. "Un decennio presidenziale." Comunicazione Politica 5: 25-36.

Calise, M. 2016. La Democrazia del Leader. Roma-Bari: Laterza.

Calise, M. 2005. "Presidentialization. Italian Style." In The Presidentialization of Politics. A Comparative Study of Modern Societies, edited by T. Poguntke and P. Webb. Oxford: Oxford University Press.

Campbell, A., P. E. Converse, W. E. Miller, and D. Stokes. 1960. The American Voter. New York: Wiley.

Campus, D. 2010. "Mediatization and Personalization of Politics in Italy and France: The Cases of Berlusconi and Sarkozy." International Journal of Press/Politics 20: 1-17.

Campus, D., and G. Pasquino. 2006. "Leadership in Italy: The Changing Role of Leaders in Elections and in Government." Journal of Contemporary European Studies 14: 25-40. doi:10.1080/14782800600617912.

Dalton, R. 2010. "Ideology, Parisanship and Democratic Development." In Comparing Democracies 3. Elections and Voting in the 21st Century, edited by L. LeDuc, R. Niemi, and P. Norris. New York: Sage Publications.

Diamanti, I., ed. 2014. The Five-Star Movement: A New Political Actor on the Web, in the Streets and on Stage. Special Issue of "Contemporary Italian Politics". Hoboken: John Wiley \& Sons

Fiorina, M. P. 1981. Retrospective Voting In American National Elections. New Haven: Yale University Press.

Flacco, F. 2014. "Leader Effect on Partisanship in Central and Eastern Europe." Paper presented at the 8th ECPR General Conference, Glasgow, September 3-6.

Garzia, D. 2012. "Party and Leader Effects in Parliamentary Elections: Towards a Reassessment." Politics 32: 175-185. doi:10.1111/j.1467-9256.2012.01443.x.

Garzia, D. 2013a. "Can Candidates' Image Win Elections? A Counterfactual Assessment of Leader Effects in the Second Italian Republic." Journal of Political Marketing 12: 348-361. doi:10.1080/15377857.2013.837303.

Garzia, D. 2013b. “The Rise of Party/Leader Identification in Western Europe.” Political Research Quarterly 66 (3): 533-544. doi:10.1177/1065912912463122.

Garzia, D., and F. Viotti. 2011. "Leader, Identità Di Partito E Voto In Italia, 1990-2008." Rivista Italiana Di Scienza Politica 41: 411-432.

Gilbert, M. 1995. The Italian Revolution: The End of Politics, Italian Style? Boudler: Westview Press.

Gunther, R. 2005. "Parties and Electoral Behavior in Southern Europe." Comparative Politics 37: 253-275. doi:10.2307/20072889.

Gunther, R., and J. Montero. 2001. "The Anchors of Partisanship: A Comparative Analysis of Voting Behavior in Four Southern European Democracies." In Parties, Politics, and Democracy in the New Southern Europe, edited by N. Diamandouros and R. Gunther. Baltimore: The Johns Hopkins University Press.

Huang, K. P. 2013. "Social and Ideological Sources of Partisanship." Asianbarometer Working Paper Series 93. Taipei: Asianbarometer

Ignazi, P. 1997. I Partiti Italiani. Bologna: Il Mulino.

Lisi, M. 2014. "Partisanship and Age Effects in Recent Democracies: Southern Europe from a Comparative Perspective." Comparative European Politics 13: 493-513. doi:10.1057/cep.2014.3.

Lobo, M. C. 2008. "Parties and Leader Effects Impact of Leaders in the Vote for Different Types of Parties." Party Politics 14 (3): 281-298. doi:10.1177/1354068807088123.

Mair, P., W. C. Müller, and F. Plasser, eds. 2004. Political Parties And Electoral Change: Party Responses To Electoral Markets. Thousand Oaks: Sage.

Marsh, M., and L. Schwirz. 2016. "Exploring the Non-Alignment of Party and Candidate Assessments in Ireland: Do Voters Really Follow Candidates?" In The Act Of Voting. Identities, Institutions And Locale, edited by J. xElkink and D. Farrell. Abingdon: Routledge.

McAllister, I. 2007. "Personalization Of Politics." In The Oxford Handbook Of Political Behavior, edited by R. Dalton and H.-D. Klingemann. Oxford: Oxford University Press. 
Miller, W. E. 1991. "Party Identification, Realignment, and Party Voting: Back to the Basics." American Political Science Review 85 (2): 557-568. doi:10.2307/1963175.

Musella, F., and P. Webb. 2015. The Personal Leader in Contemporary Party Politics. Special Issue of "Italian Political Science Review". Cambridge: Cambridge University Press

Page, B. I., and C. C. Jones. 1979. "Reciprocal Effects of Policy Preferences, Party Loyalties and the Vote." American Political Science Review 73 (4): 1071-1089. doi:10.2307/1953990.

Pasquino, G. 1990. "Personae non gratae? Personalizzazione e spettacolarizzazione della politica." Polis 4: 207-208.

Pasquino, G., and P. McCarthy, eds. 1993. The End of Post-War Politics in Italy. The Landmark 1992 Elections. Boulder: Westview Press.

Poli, E. 2001. Forza Italia. Strutture, leadership e radicamento territoriale. Bologna: Il Mulino.

Rahat, G., and T. Sheafer. 2007. "The Personalization (s) of Politics: Israel, 1949-2003.” Political Communication 24: 65-80. doi:10.1080/10584600601128739.

Richardson, B. M. 1991. "European Party Loyalties Revisited." American Political Science Review 85: 751-775. doi:10.2307/1963849.

Tronconi, F. 2005. "Identità etnica e competizione politica: un'analisi del voto ai partiti etnoregionalisti in Europa occidentale.” Rivista Italiana di Scienza Politica 35: 77-106.

Venturino, F. 2000. "La personalizzazione della politica italiana. Il ruolo dei leader nelle elezioni del 1996." Rivista Italiana di Scienza Politica 30: 295-327.

Vicentini, G. 2015. "From 'Foreign Body'to the Party Leadership and Beyond: Explaining Matteo Renzi's Path to Power through the Evolution of His Primary Election Voters." Contemporary Italian Politics 7: 127-143. doi:10.1080/23248823.2015.1039244.

Wooldridge, J. M. 2001. Econometric Analysis Of Cross Section And Panel Data. Boston: MIT Press. 


\section{Appendices}

\section{Appendix 1. Detailed variable coding}

Gender (0) male; (1) female

Age category (1) 18-24; (2) 25-34; (3) 35-44; (4) 45-54; (5) 55-64; (6) 65+

Level of education (1) elementare; (2) media inferiore; (3) superiori di corso; (4) dipoloma di istituto professionale; (5) diploma di maturitá; (6) universitá in corso; (7) diploma universitario; (8) laurea triennale; (9) laurea specialistica; (10) master/scuola di specializzazione; (11) $\mathrm{PhD}$

Public-sector employee (0) no; (1) yes

Private-sector employee (0) no; (1) yes

Church attendance (1) never; (2) a few times a year; (3) on the occasion of traditional celebrations; (4) once a month; (5) every Sunday; (6) 2/3 times a week; (7) every day

Left-right proximity Absolute difference between respondent's self-placement on the 10-point left-right scale and the perceived position of a given party on the same scale

Leader's thermometer Scale from 0 (totally negative) to 10 (totally positive).

\section{Appendix 2. Robustness tests}

Table A1. The determinants of partisanship: OLS estimation.

\begin{tabular}{lcr}
\hline & $\mathrm{FI}$ & $\mathrm{NCD}$ \\
\hline Leader Evaluation (t2) & $.59(.05)^{* *}$ & $.58(.07)^{* *}$ \\
Left/Right Proximity (t2) & $-.21(.07)^{* *}$ & $-.21(.08)^{* *}$ \\
Closeness to PdL (t1) & $.39(.08)^{* *}$ & $.25(.08)^{* *}$ \\
R-Squared & .67 & .44 \\
$\mathrm{~N}$ & 210 & 210 \\
\hline
\end{tabular}

Analysis includes only those respondents rating their closeness to each of the parties being analysed between 5 and 10 at $\mathrm{t} 1$. Cell entries are OLS un-standardised regression coefficients (standard error in parentheses). ${ }^{* *} \mathrm{p}<.01$ Controls include: gender, age, education, occupational status, frequency of church attendance (coefficients not shown).

Table A2. The drivers of change: first difference (FD) estimation.

\begin{tabular}{lcc}
\hline & LN & PD \\
\hline$\Delta$ Leader Evaluation & $.13(.08)$ & $.09(.04)^{*}$ \\
$\Delta$ Left/Right Proximity & $-.17(.10)$ & $.05(.06)$ \\
R-Squared & .12 & .10 \\
$\mathrm{~N}$ & 144 & 252 \\
\hline
\end{tabular}

Analysis includes only those respondents rating their closeness to each of the parties being analysed between 5 and 10 at $\mathrm{t} 1$. Cell entries are OLS un-standardised regression coefficients (standard error in parentheses). ${ }^{*} p<.05$ Controls include: gender, age, education, occupational status, frequency of church attendance (coefficients not shown). 